\title{
Short communication: Characterization of a monoclonal antibody for $\kappa$-casein B of cow's milk ${ }^{1}$
}

\author{
A. Summer, ${ }^{\star}$ E. Santus,† L. Casanova,† H. Joerg,§ A. Rossoni,† C. Nicoletti, ${ }^{\dagger}$ G. Donofrio,\# P. Mariani, ${ }^{\star}$ \\ and M. Malacarne*2 \\ *Department of Animal Production, Veterinary Biotechnologies, Food Quality and Safety, University of Parma, via del Taglio 10, \\ 43126 Parma, Italy \\ †ANARB - Italian Brown Cattle Breeders' Association, Loc. Ferlina 204, 37012 Bussolengo (VR), Italy \\ ¥SBZW—Swiss Brown Cattle Breeders Federation, Chamerstrasse 56, CH-6300 Zug, Switzerland \\ §Qualitas AG, Chamerstrasse 56, CH-6300 Zug, Switzerland \\ \#Department of Animal Health, University of Parma, via del Taglio 10, 43126 Parma Italy
}

\section{ABSTRACT}

A monoclonal antibody (antik-B) against an oligopeptide of 23 AA corresponding to the region 131-153 of bovine $\kappa$-casein $(\kappa-\mathrm{CN}) \mathrm{B}$ was generated using the Human Combinatorial Antibody Library (HuCAL) technology. Both AA substitutions distinguishing $\kappa-\mathrm{CN}$ $\mathrm{A}$ and $\mathrm{B}$ are located in that region (positions 136 and 148). In this study, the reactivity of antik-B to milk samples collected from cows previously genotyped as $C S N 3^{*} A A, C S N 3^{*} A B$, and $C S N 3^{*} B B$ was tested. According to Western blot results, antik-B recognized $\kappa-\mathrm{CN} B$ and it showed no cross-reactivity toward $\kappa-\mathrm{CN}$ $\mathrm{A}$ and other milk proteins. Furthermore, a modified Western blot method, urea-PAGE Western blot, was set up to assess the reactivity of antik-B toward all isoforms of $\kappa-\mathrm{CN}$ B. In conclusion, antik-B was specific to $\mathrm{k}-\mathrm{CN} \mathrm{B}$ in milk and it seemed to be reactive toward all its isoforms.

Key words: bovine milk, $\kappa$-casein $\mathrm{B}$, monoclonal antibody

א-Casein, which represents approximately $15 \%$ of total CN (Alais, 1984), is the most interesting and important $\mathrm{CN}$ component in that it is centrally involved in the formation and stabilization of $\mathrm{CN}$ micelles, the coagulation of milk by rennet, and many other technologically important functions of the milk protein system. The functional duality of $\kappa-\mathrm{CN}$, which is to interact hydrophobically with other $\mathrm{CN}$ and at the

\footnotetext{
Received August 11, 2009.

Accepted October 26, 2009.

${ }^{1}$ An ELISA test to quantify $\kappa-\mathrm{CN} \mathrm{B}$, as described in the Materials and Methods, has been internationally patented (patent: PCT/ IB2008/002680; author: Andrea Summer; year: 2008; title: "Method of determination of $\kappa$-casein in bulk milk samples," Italy) by the Italian Brown Swiss Organization and the Swiss Brown Cattle Breeders Federation. The authors of this manuscript do not receive royalties related to this patent.

${ }^{2}$ Corresponding author: massimo.malacarne@unipr.it
}

same time provide a hydrophilic and negatively charged surface on the micelle to stabilize the colloidal suspension, is strikingly reflected by its amphipathic primary structure (Swaisgood, 2003). Its hydrophilic and flexible C-terminal part (caseinomacropeptide, or CMP) is cleaved specifically by chymosin (between residues Phe105 and Met106), thus leading to the destabilization of the micelle [to which the highly hydrophobic and insoluble N-terminal part (para- $\kappa$-CN) remains anchored (De Kruif and Holt, 2003)] and the formation of the curd.

Thirteen genetic variants of $\kappa$-CN have been identified to date (for a review, see Formaggioni et al., 1999). The 2 widely diffused genetic variants are designated $\mathrm{A}$ and B (Baker and Manwell, 1980). $\kappa$-Casein B differs from the A variant by substitution of an Ile residue for Thr at position 136 and an Ala residue for Asp at position 148 (Grosclaude et al., 1972). Compared with к-CN A, $\kappa-\mathrm{CN} B$ is associated with higher casein content (NgKwai-Hang et al., 1986) with higher $\kappa$-CN proportion (Kroeker et al., 1985; Mariani et al., 1995), resulting in smaller micelles (Nielsen et al., 1982; Donnelly et al., 1984; Pearse et al., 1986), which in turn leads to improved curd properties (Niki and Arima, 1984; Pearse et al., 1986) and higher cheese yield (Mariani et al., 1976; Walsh et al., 1998a,b).

Because of the remarkable effects exerted by the B variant of $\kappa$-CN on the cheesemaking process, it appears useful to introduce $\kappa$-CN content $\mathrm{B}$ into milk quality payment systems. For this purpose, it is necessary to point out a practical, fast, and reliable system that allows the quantification of the presence of the B variant at the level of bulk milk samples. An indirect competitive ELISA rapid test was recently submitted for patenting by the Italian Brown Cattle Breeders Association and the Swiss Brown Cattle Breeders Federation. The key element of the test is a monoclonal antibody (antik-B) that is specific to the sequence 131-153 of the B variant of cow's milk k-CN. 
This paper reports the characterization of the immunological behavior of antik-B in individual milk samples from cows previously genotyped as $\mathrm{BB}, \mathrm{AB}$, or $\mathrm{AA}$ at the $\kappa-\mathrm{CN}$ locus. Using the Human Combinatorial Antibody Library (HuCAL; www.morphosys.com/ en/technologies/hucal-136.html) technology, antik-B against the sequence 131-153 of bovine k-CN B (GenBank accession number AAQ87923.1) was generated by Morphosys (Martinsried, Germany). The antibody was tested against the milk of 9 Italian Brown cows that were previously genotyped at the $\kappa-\mathrm{CN}$ locus as $\mathrm{BB}$ (3 cows), AA (3 cows), and AB (3 cows) by means of urea-PAGE (Andrews, 1986). Individual milk samples from the 9 selected cows were collected during morning milking. Raw milk samples were transferred to the laboratory within $15 \mathrm{~min}$ and analyzed immediately. Milk pH and SCC were determined with a potentiometer (Crison Instruments, Barcelona, Spain) and Fossomatic (Foss, Hillerød, Denmark), respectively. Skim milk was obtained as follows: raw milk was warmed to $40^{\circ} \mathrm{C}$ and kept at this temperature for $10 \mathrm{~min}$, and then centrifuged at $1,800 \times g$ for $15 \mathrm{~min}$; the resulting fat layer was removed by gentle aspiration with a vacuum pump. Rennet-whey samples were obtained according to Verma and Sommer (1957). Briefly, $2 \mathrm{~mL}$ of a rennet solution $(1: 100,000$, Chr. Hansen, Corsico MI, Italy) was added to $100 \mathrm{~mL}$ of a milk sample kept at $37^{\circ} \mathrm{C}$. Ten minutes after the visible formation of the coagulum, rennet whey was separated by filtration of the soluble phase on filter papers (Whatman 1, Whatman International Ltd., Maidstone, UK). To prepare milk + rennet samples, rennet was added to raw milk as described previously. Four aliquots of $200 \mu \mathrm{L}$ (at 0 and 10, 20, and $30 \mathrm{~min}$ after rennet addition) were transferred to Eppendorf tubes containing $800 \mu \mathrm{L}$ of a 15\% TCA solution. Western blot (WB) analysis was carried out as follows: skim milk, rennet whey, and milk + rennet samples were electrophoresed through $12 \%$ SDS-PAGE according to Laemmli (1970) and blotted onto a polyvinyl difluoride membrane. After blotting, the polyvinyl difluoride membrane was saturated for 1 $\mathrm{h}$ at $37^{\circ} \mathrm{C}$ with $5 \%$ BSA in Tris-buffered saline Tween [TBST; $50 \mathrm{~m} M$ Tris/HCl, $150 \mathrm{~m} M \mathrm{NaCl}, 0.1 \%$ (vol/vol) Tween 20; pH 7.5] buffer. Each membrane was rinsed 3 times with $15 \mathrm{~mL}$ of TBST. Primary incubation was performed overnight at $4^{\circ} \mathrm{C}$ with antik-B in TBST containing $1 \%$ BSA. Membrane was then probed at $37^{\circ} \mathrm{C}$ for $1 \mathrm{~h}$ with horseradish peroxidase-labeled anti-human immunoglobulin G F(ab') antibody (AbD Serotec, Martinsried, Germany) in TBST containing 1\% BSA and then visualized by enhanced chemiluminescence (ECL Kit, Pierce, Rockford, IL). Oligopeptides of 23 AA corresponding to the sequence $131-153$ of both $\kappa-\mathrm{CN}$
$\mathrm{B}$ and $\mathrm{A}$ were used as positive and negative controls, respectively, in WB analysis. Both oligopeptides were conjugated to transferrin (TRF) and were produced by Morphosys. A modified WB procedure (urea-PAGE WB) was performed as well. In this method, skim milk samples were electrophoresed through urea-PAGE according to Andrews (1986). Prior to blotting, the gel was equilibrated as follows: $15 \mathrm{~min}$ in $50 \mathrm{~mL}$ of $1 M$ Tris (pH 8), $10 \mathrm{~min}$ in $50 \mathrm{~mL}$ of $10 \times$ transfer buffer $(25 \mathrm{mM}$ Tris, $196 \mathrm{~m} M$ glycine, $10 \%$ methanol), and $10 \mathrm{~min}$ in 50 $\mathrm{mL}$ of transfer buffer containing $20 \%$ methanol. After this step, the gel underwent standard WB procedure.

Milk $\mathrm{pH}$ values $($ mean $=6.71$, minimum $=6.62$, maximum $=6.76$ ) were in the normal range for cow's milk. Eight out of 9 milk samples showed an SCC below 400,000 cells/mL, which is the European threshold limit for milk destined for cheesemaking. One milk sample was characterized by a somatic cell value above this limit $(552,000$ cells $/ \mathrm{mL})$. However, because both the milk sample and cow's udder did not show clinical signs of mastitis and because at this somatic cell level $\mathrm{k}$-CN should not be affected by proteolysis, this sample was also analyzed. The WB analysis of negative and positive control, skim milk, and rennet whey from $C S N 3^{*} B B, C S N 3^{*} A B$, and $C S N 3^{*} A A$ cows is reported in Figure 1. A specific peptide (pep1) was detected by antik-B in skim milk samples from $C S N 3^{*} B B$ and $C S N 3^{*} A B$ cows. According to SDS-PAGE migration profile, pep1 was positioned in the zone of $\kappa-\mathrm{CN}$ and it was detectable only in milk samples from cows carrying the $\mathrm{B}$ allele at the CSN3 locus. Furthermore, the band corresponding to pep1 was more clearly marked in the milk sample from the $C S N 3^{*} B B$ cows than in that from the $C S N 3^{*} A B$ cows. On the basis of these observations, pep1 could be hypothetically assigned to $\kappa-\mathrm{CN}$ B. A second peptide (pep2) was recognized by antik-B in rennet whey from $C S N 3^{*} B B$ and $C S N 3^{*} A B$ cows. According to migration pattern, pep2 should be smaller than pep1. Because pep2 was detected only in rennet whey of $C S N 3^{*} B B$ and $C S N 3^{*} A B$ cows, it could be hypothetically assigned to CMP arising from the cleavage of $\kappa-\mathrm{CN} B$ by chymosin. In fact, the antibody recognizes a sequence (131-153) that is included in CMP fragment. No peptides were recognized by antik-B in skim milk and rennet whey samples from the $C S N 3^{*} A A$ cows. To verify the hypothetical assignation of pep1 and pep2 to $\kappa-\mathrm{CN} \mathrm{B}$ and the corresponding $\mathrm{CMP}$, respectively, the milk sample from the $C S N 3^{*} B B$ cows was treated with rennet (Figure 2). In normal milk, the formation of curd takes place when $>90 \%$ of the $\kappa-\mathrm{CN}$ is specifically hydrolyzed by the chymosin (the clotting enzyme present in rennet; Dalgleish, 1979); in the conditions adopted here, it takes about $20 \mathrm{~min}$. 


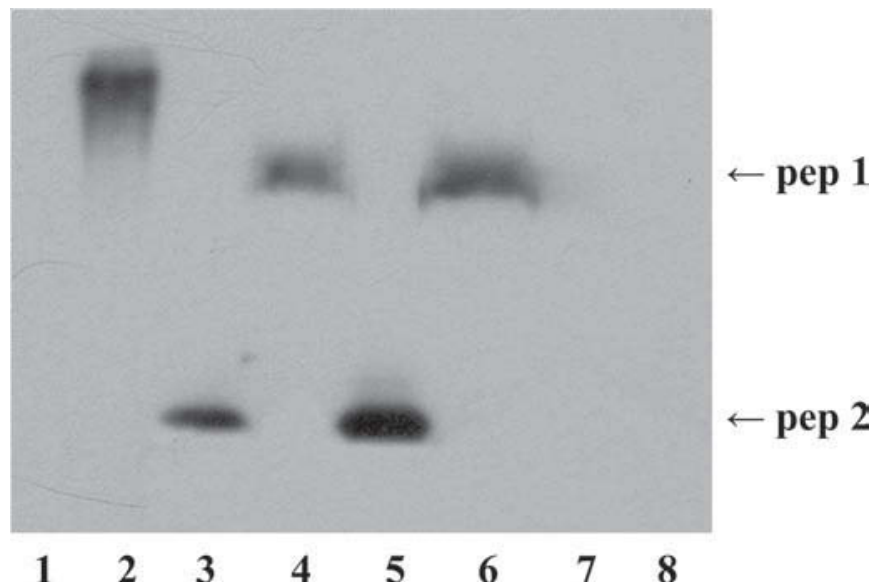

Figure 1. Characterization of a monoclonal antibody specific to bovine $\kappa-\mathrm{CN}$ B: Western blot of individual milk samples and rennet whey. Lane 1: oligopeptide of $23 \mathrm{AA}$, corresponding to the region 131-153 of $\kappa-\mathrm{CN}$ A, conjugated to transferrin. Lane 2: oligopeptide of $23 \mathrm{AA}$, corresponding to the region $131-153$ of $\kappa-\mathrm{CN}$ B, conjugated to transferrin. Lanes 3 and 4: rennet whey and skim milk, respectively, from a $C S N 3^{*} A B$ cow. Lanes 5 and 6: rennet whey and skim milk, respectively, from a $C S N 3^{*} B B$ cow. Lanes 7 and 8: rennet whey and skim milk, respectively, from a $C S N 3^{*} A A$ cow. pep = peptide.

In this experiment, rennet was added to milk and 4 aliquots were collected at 0 and 10, 20, and $30 \mathrm{~min}$ after rennet addition. Each aliquot was immediately treated with TCA to denature and precipitate proteins and, thus, stop reaction between $\mathrm{\kappa}-\mathrm{CN}$ and chymosin.

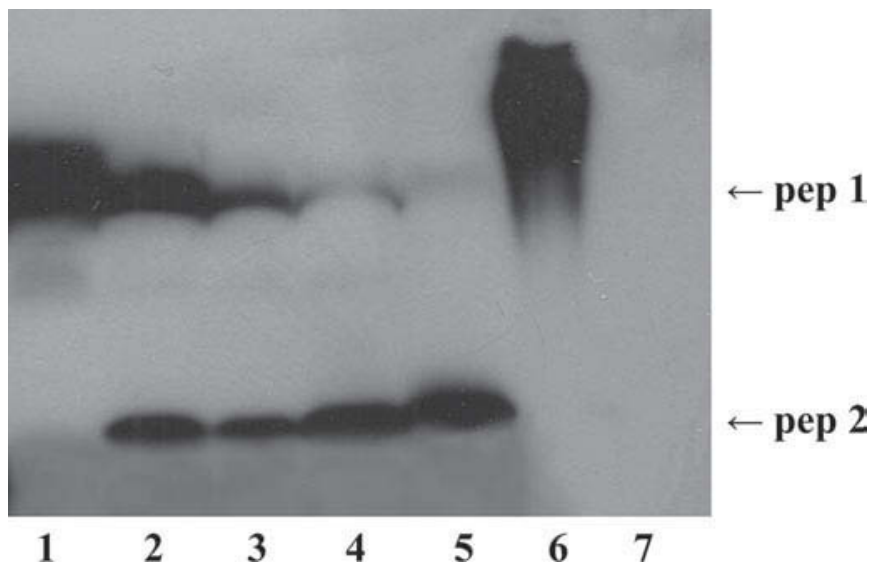

Figure 2. Characterization of a monoclonal antibody specific to bovine $\kappa-\mathrm{CN}$ B: Western blot of an individual milk sample from a $C S N 3{ }^{*} B B$ cow analyzed at 10 -min intervals from rennet addition Lane 1: milk added with rennet (milk + rennet) at time 0 . Lane 2: milk + rennet after $10 \mathrm{~min}$. Lane 3: milk + rennet after $20 \mathrm{~min}$. Lane 4: milk + rennet after 30 min. Lane 5: rennet whey from a $C S N 3^{*} B B$ cow. Lane 6: oligopeptide of $23 \mathrm{AA}$, corresponding to the region 131153 of $\kappa-\mathrm{CN} \mathrm{B}$, conjugated to transferrin. Lane 7: oligopeptide of 23 AA, corresponding to the region $131-153$ of $\kappa-\mathrm{CN}$ A, conjugated to transferrin. pep $=$ peptide.

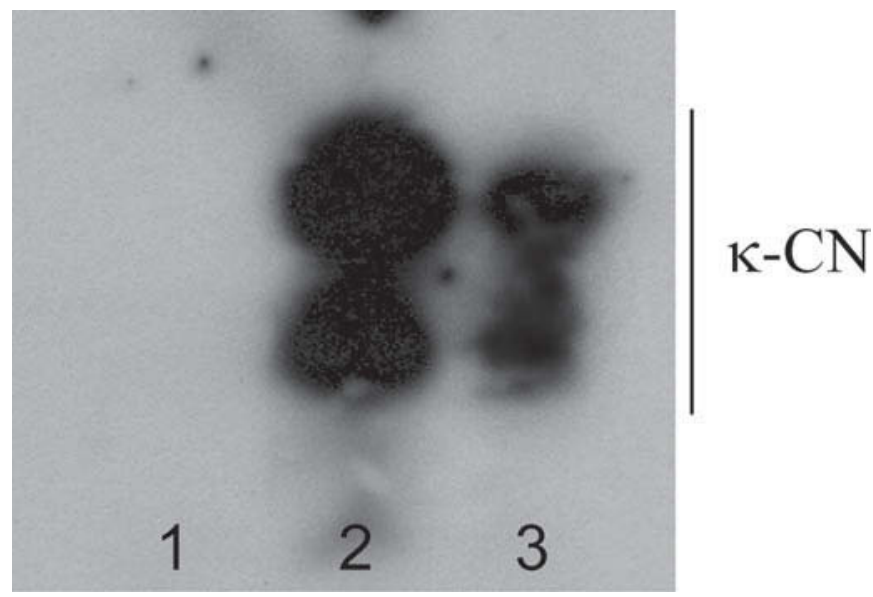

Figure 3. Characterization of a monoclonal antibody specific to bovine $\kappa-\mathrm{CN}$ B: urea-PAGE Western blot of individual milk samples. Lane 1: skim milk from a $C S N 3^{*} A A$ cow. Lane 2: skim milk from a $\operatorname{CSN}^{*} B B$ cow. Lane 3: skim milk from a $C S N 3^{*} A B$ cow.

The aliquots were then analyzed in SDS-PAGE WB with antik-B. The result of this experiment is reported in Figure 2. As time from rennet addition increased, pep1 decreased in intensity, and it disappeared after 30 min. On the other hand, pep2, which was not detectable at time 0 , increased in intensity from 10 to 30 min after rennet addition. According to these results, pep1 and pep2 corresponded to native $\kappa-\mathrm{CN} \mathrm{B}$ and the correspondent CMP, respectively. To complete the characterization of the monoclonal antibody, its reactivity toward all the isoforms of $\kappa-\mathrm{CN}$ present in milk was checked as well. It is well known that the major fraction of $\kappa-\mathrm{CN}$ is present in a nonglycosylated form (Mariani et al., 1995). However, even if in a lesser amount, there are minor fractions of $\kappa-\mathrm{CN}$ with a different degree of glycosylation (isoforms). To employ the monoclonal antibody in a quantitative method, it was necessary to test the affinity of the antibody toward all the isoforms of $\kappa$-CN B. To this end, milk samples from $C S N 3^{*} B B$ and $C S N 3^{*} A A$ cows were analyzed in urea-PAGE WB (Figure 3). The migration patterns of $\kappa-\mathrm{CN}$ and its glycosylated isoforms in urea-PAGE electrophoresis were reported by Egito et al. (2001). These authors proved that in urea-PAGE $\kappa-\mathrm{CN}$ isoforms give rise to several fast-migrating bands compared with the nonglycosylated form. The presence of several bands was caused by the different degree of glycosylation of $\kappa$-CN. According to these electrophoretic profiles, if the antibody was specific against only 1 isoform of $\kappa-\mathrm{CN}$, a discrete band (as the one observed in SDS-PAGE WB) was expected to appear. Otherwise, if the antibody recognized all the glycosylated forms of $\kappa-\mathrm{CN}$, a smear band was expected. A smear band was observed in milk 
samples with the $\mathrm{B}$ variant of $\kappa-\mathrm{CN}$ (lane 2, Figure 3). According to its intensity, the reaction of the monoclonal antibody was clearly higher in $\kappa$-CN BB milk (lane 2, Figure 3) than in $\mathrm{k}-\mathrm{CN} \mathrm{AB}$ milk (lane 3, Figure 3). The differences of intensity were probably related to the higher content of $\kappa-\mathrm{CN} \mathrm{B}$ in milk from $C S N 3^{*} B B$ cows than in milk from $C S N 3^{*} A B$ cows. The shape of the band (a smear) is likely a result of the reaction of the monoclonal antibody with the different isoforms of $\kappa-\mathrm{CN}$ B. The AA sequence 131-153 of $\kappa-\mathrm{CN}$ B used to select the monoclonal antibody is shared by the variants C (Miranda et al., 1993) and J (Mahé et al., 1999) of $\kappa-\mathrm{CN}$. Furthermore, the variant $\mathrm{B}^{2}$ (characterized only at cDNA level) differs in that region for a single AA substitution: Thr in 153 (Gorodetskij and Kaledin, 1987). These variants are potentially recognizable by antik-B, particularly $\mathrm{C}$ and $\mathrm{J}$. The presence of $\kappa-\mathrm{CN} \mathrm{C}$ was reported with very low frequencies in milk of Grey Alpine (Di Stasio and Merlin, 1979) and Italian Brown (Caroli et al., 2004) cows (0.007 and 0.003, respectively), and it was not detected at all in milk of Italian Friesian cows (Caroli et al., 2004). Other potentially cross-reactive variants- $\mathrm{B}^{2}$ and, in particular, J-are rare variants in dairy cattle, detected in populations with very limited diffusion and with low allele frequencies. For these reasons, the possibility of overestimating the content of $\kappa-\mathrm{CN} B$ in bulk milk samples owing to the presence of potentially recognizable genetic variants should be considered very low. Based on the results, the monoclonal antibody, employed in the ELISA test, is specific toward $\kappa-\mathrm{CN} \mathrm{B}$ and its isoforms, and it shows no cross-reactivity toward $\kappa-\mathrm{CN} \mathrm{A}$ and other milk proteins. This would permit the introduction of $\kappa-\mathrm{CN} B$ content into quality payment systems for cheese milk. For example, in Parmigiano-Reggiano cheese production, the current pricing of milk is based on quantity of milk delivered to the cheese farm and on a milk quality payment system at herd milk level. The quality score is assessed on the basis of the values of some herd milk characteristics (mainly fat and casein content, titratable acidity, total bacterial count, and somatic cell content) recorded each $15 \mathrm{~d}$. Because of the positive effects on milk processability, cheese yield, and quality, $\kappa-\mathrm{CN} B$ content would be a promising parameter to introduce into milk quality payment system scoring.

\section{REFERENCES}

Alais, C. 1984. Science du Lait. Principes des Techniques Laitières. 4th ed. Edition SEPAIC, Paris, France.

Andrews, A. T. 1986. Polyacrylamide gel electrophoresis using multiphasic buffer systems. Pages 79-92 in Electrophoresis: Theory, Techniques, and Biochemical and Clinical Applications. A. R. Peacocke and W. F. Harrington, ed. Clarendon Press, Oxford, UK.
Baker, C. M. A., and C. Manwell. 1980. Chemical classification of cattle. 1. Breed groups. Anim. Blood Groups Biochem. Genet. 11:127-150.

Caroli, A., S. Chessa, P. Bolla, E. Budelli, and G. C. Gandini. 2004. Genetic structure of milk protein polymorphisms and effects on milk production traits in a local dairy cattle. J. Anim. Breed. Genet. 121:119-127.

Dalgleish, D. G. 1979. Proteolysis and aggregation of casein micelles treated with immobilized or soluble chymosin. J. Dairy Res. 46:653-661.

De Kruif, C. G., and C. Holt. 2003. Casein micelle structure, functions and interactions. Pages 233-276 in Advanced Dairy Chemistry: Proteins. Vol. 1. P. F. Fox and P. L. H. McSweeney, ed. Kluwer Academic, London, UK.

Di Stasio, L., and P. Merlin. 1979. Polimorfismi biochimici del latte nella razza bovina Grigio Alpina. Riv. Zootec. Vet. 7:64-67.

Donnelly, W. J., G. P. McNeill, W. Buchheim, and T. C. A. McGann. 1984. A comprehensive study of the relationships between size and protein composition in natural bovine casein micelles. Biochim. Biophys. Acta 789:136-143.

Egito, A. S., J.-M. Girardet, L. Miclo, and J.-L. Gaillard. 2001. Highly sensitive periodic acid/Schiff detection of bovine milk glycoproteins electrotransferred after nondenaturing electrophoresis, urea electrophoresis, and isoelectric focusing. Lait 81:775-785.

Formaggioni, P., A. Summer, M. Malacarne, and P. Mariani. 1999 Milk protein polymorphism: Detection and diffusion of the genetic variants in Bos genus. Ann. Fac. Med. Vet. Univ. Parma XIX:127165.

Gorodetskij, S. I., and A. S. Kaledin. 1987. Analysis of nucleotide sequence of bovine K-casein. Genetika USSR 23:596-604.

Grosclaude, F., M.-F. Mahé, J.-C. Mercier, and B. Ribadeau-Dumas. 1972. Localisation des substitutions d'acides aminés différenciant les variants A et B de la caséine $\kappa$ bovine. Ann. Genet. Sel. Anim. 4:515-521.

Kroeker, E. M., K. F. Ng-Kwai-Hang, K. F. Hayes, and J. E. Moxley. 1985. Effects of environmental factors and milk protein polymorphism on composition of casein fraction in bovine milk. J. Dairy Sci. 68:1752-1757.

Laemmli, U. K. 1970. Cleavage of structural proteins during assembly of the head of bacteriophage T4. Nature 227:680-685.

Mahé, M. F., G. Miranda, R. Queval, A. Bado, P. SouvenirZafindrajaona, and F. Grosclaude. 1999. Genetic polymorphism of milk proteins in African Bos taurus and Bos indicus populations. Characterization of variants $\alpha_{\mathrm{S} 1}-\mathrm{Cn} \mathrm{H}$ and $\kappa$-Cn J. Genet. Sel. Evol. 31:239-253.

Mariani, P., G. Losi, V. Russo, G. B. Castagnetti, L. Grazia, D. Morini, and E. Fossa. 1976. Cheesemaking tests made with milk characterized by variants $\mathrm{A}$ and $\mathrm{B}$ of $\kappa$-casein in the production of Parmigiano-Reggiano cheese. Sci. Tecn. Latt. Cas. 27:208-227.

Mariani, P., G. Zanzucchi, M. Masoni, P. Serventi, and M. Pecorari 1995. Percentage distribution of caseins and the kappa-casein fractions, separated by RP-HPLC, in Italian Brown cows with different genotype at the K-CN locus. Sci. Tecn. Latt. Cas. 46:2035 .

Miranda, G., P. Anglade, M. F. Mahé, and G. Erhardt. 1993. Biochemical characterization of the bovine genetic kappa-casein $\mathrm{C}$ and $\mathrm{E}$ variants. Anim. Genet. 24:27-31.

Ng-Kwai-Hang, K. F., J. F. Hayes, J. E. Moxley, and H. G. Monardes. 1986. Relationships between milk protein polymorphisms and major milk constituents in Holstein-Friesian cows. J. Dairy Sci. 69:22-26.

Nielsen, E. W., G. Berntsen, S. Hansen, B. V. Larsen, and D. Edelsten. 1982. Rennet coagulation of casein micelles of different size. Proc. XXI International Dairy Congress 1:257-258. Mir Publishers, Moscow, Russia.

Niki, R., and S. Arima. 1984. Effects of size of casein micelle on firmness of rennet curd. Jpn. J. Zootech. Sci. 55:409-415.

Pearse, M. J., P. M. Linklater, R. J. Hall, and A. G. MacKinlay. 1986. Effect of casein micelle composition and casein dephosphorylation on coagulation and syneresis. J. Dairy Res. 53:381-390. 
Swaisgood, H. E. 2003. Chemistry of casein. Pages 139-201 in Advanced Dairy Chemistry. Proteins. Vol. 1. P. F. Fox and P. L. H. McSweeney, ed. Kluwer Academic, London, UK.

Verma, I. S., and H. H. Sommer. 1957. Study of the naturally occurring salts in milk. J. Dairy Sci. 40:331-335.

Walsh, C. D., T. P. Guinee, D. Harrington, R. A. J. Mehra, J. Murphy, and R. J. Fitzgerald. 1998a. Cheesemaking, compositional and functional characteristics of low-moisture part-skim Mozzarella cheese from bovine milks containing $\kappa$-casein $\mathrm{AA}, \mathrm{AB}$ or $\mathrm{BB}$ genetic variants. J. Dairy Res. 65:307-315.

Walsh, C. D., T. P. Guinee, W. D. Reville, D. Harrington, J. J. Murphy, B. T. O'Kennedy, and R. J. Fitzgerald. 1998b. Influence of $\kappa$-casein genetic variant on rennet gel microstructure, Cheddar cheesemaking properties, and casein micelle size. Int. Dairy J. 8:707-714. 